\title{
PENGARUH PEMBERIAN BEBERAPA JENIS BAHAN ORGANIK TERHADAP PENINGKATAN KANDUNGAN HARA N, P, K ULTISOL KEBUN PERCOBAAN FAPERTA UNAND PADANG
}

\author{
Gusmini, Yulnafatmawita, dan Anita Febriani Daulay \\ F akultas Pertanian U niversitas Andalas
}

\begin{abstract}
A research entitled the effect of various sources of organic matter on improvement of $\mathrm{N}, \mathrm{P}, \mathrm{K}$ Nutrient of Ultisol was conducted in Limau Manis Padang. The research was aimed to investigate the contribution of different source of organic matter to improve N,P,K content in soil. Field research was arranged in Randomized Block Design (RBD) consisting 5 treatments and 3 replications (blocks). Treatments are : $\mathrm{A}=$ no organic matter added, $\mathrm{B}=$ Tithonia, $\mathrm{C}=$ Paddy Straw, D = Imperata cylindrica, and E = Leucaena glauca. The dosage for each treatment was 20 ton/ha. The result showed that tithonia gave the best contribution in improving N,P,K content of Ultisol Limau Manis.
\end{abstract}

Keywords : organic matter, N, P, K of Ultisols.

\section{PENDAHULUAN}

Ultisol menempati bahagian terluas dari lahan kering di Indonesia yang tersebar di Sumatra, Kalimantan, Sulawesi dan Irian jaya (Hardjowigeno, 1993). Sumatra Barat, Ultisol banyak tersebar di berbagai daerah salah satunya adalah di Kebun Percobaan Fakultas Pertanian Limau Manis Padang. Jenis Ultisol didaerah ini termasuk sub ordo Udults dan sub group Orthoxic Tropudults (Imbang, Rasyidin, Adrinal, Maira dan Hermansah, 1994). Udults adalah salah satu sub group dari Ultisol, yang mempunyai rejim kelembaban tanah udik, pada iklim humid, drainase baik dengan curah hujan cukup dan terdapat pada epipedon okrik diatas horizon argilik atau horizon kandik (Fiantis, 2004).

Ultisol merupakan tanah berproduktivitas rendah, memiliki berbagai kendala seperti reaksi masam, keracunan $\mathrm{Al}$, miskin hara dengan ciri fisika, kimia dan biologi yang kurang menguntungkan, tanpa dilakukan pemupukan dan pengelolaan yang tepat tanaman yang tumbuh pada Ultisol berproduksi sangat rendah.

Ultisol yang dimanfaatkan secara terus menerus, tanpa memperhatikan pengelolaan bahan organik dan tingkat kesuburannya, mengakibatkan produktifitas tanah tersebut akan menurun. Karena

peranan bahan organik dalam tanah sangat penting, disamping sebagai penyusun padatan (agregat) tanah, juga dapat mempengaruhi sifat-sifat fisik tanah serta meningkatkan kandungan hara tanah.

Pemberian bahan organik selain
sebagai sumber hara, akan dapat memperbaiki sifat fisika, kimia dan biologi tanah. Dekomposisi bahan organik dengan bantuan mikroorganisme akan mengubah bahan organik kasar menjadi halus. Dengan pemberian bahan organik akan melindungi permukaan tanah dari butir hujan, dan memperbaiki struktur tanah, menjaga stabilitas agregat, dan meningkatkan kadar air tanah. Pembebasan asam-asam organik akan dapat mengikat $\mathrm{Al}$, sehingga mengurangi kelarutan $\mathrm{Al}$ dan menaikkan $\mathrm{pH}$ tanah.

Sifat-sifat fisika tanah merupakan salah satu sifat tanah yang cukup besar pengaruhnya terhadap pertumbuhan tanaman terutama struktur tanah, khususnya stabilitas atau kemantapan agregat tanah. Karena struktur tanah yang bagus merupakan salah satu sifat fisika tanah yang dianggap sebagai suatu penciri kualitas tanah yang baik.

Usaha peningkatan produktifitas dari Ultisol tersebut salah satunya adalah dengan meningkatkan stabilitas aggregat atau kemantapan agregat tanahnya dengan 
pemberian bahan organik. Bahan organik merupakan bahan padatan tanah yang diberikan pada tanah baik dalam keadaan segar maupun yang sudah terdekomposisi (melapuk). Usaha peningkatan produktifitas tanah dengan meningkatkan kandungan hara $\mathrm{N}, \mathrm{P}, \mathrm{K}$ dan perbaikan sifat-sifat tanah, khususnya stabilitas agregat Ultisol, salah satunya adalah dengan pemberian bahan organic

Pupuk hijau merupakan salah satu sumber bahan organik yang sudah banyak digunakan dalam pertanian. Pupuk hijau adalah tanaman atau bagian-bagian tanaman yang masih muda yang dibenamkan kedalam tanah dengan maksud agar dapat meningkatkan kandungan bahan organik dan unsur hara bagi pertumbuhan dan perkembangan tanaman (Sutedjo dan Kartasapoetra, 1989). Pupuk hijau mempunyai kelebihan dibandingkan pupuk alam lainnya, selain mampu menghasilkan bahan organik dan unsur hara, cara kerja pupuk hijau lebihmudah dan dapat diberikan secara langsung kedalam tanah. Jenis-jenis pupuk hijau yang sering digunakan adalah jenis kacang-kacangan (legumineacea).

Hasil penelitian Nedrawati (2006), menjelaskan bahwa pemberian bokasi titonia sebagai bahan organik dapat memperbaiki sifat-sifat fisika tanah Ultisol Limau Manis, sehingga terjadinya peningkatan bahan organik dari 3,48\% menjadi $4,22 \%$, serta penurunan BV dari $0,96 \mathrm{gr} / \mathrm{cm}^{3}$ menjadi $0,82 \mathrm{gr} / \mathrm{cm}^{3}$ dan peningkatan total ruang pori (TRP) dari $62,4 \%$ menjadi $68,8 \%$.

Sumber bahan organik yang diperlakukan sebagai mulsa seperti alangalang dan jerami padi, dapat mempengaruhi sifat-sifat fisik, dan hara tanah, karena selain sebagai sumber hara setelah melapuk, dapat juga berfungsi memperbesar ketersediaan air tanah, penyerapan air lebih optimal ( Jacks et al, 1975 cit Ridwan, 1985).

Bahan organik yang digunakan dalam penelitian ini yaitu tithonia (Tithonia diversifolia), alang-alang (Imperata cylindrica), jerami padi, dan petai cina (Leucaena glauca), yang langsung dicampur dengan tanah berupa bahan organik segar (tanpa pengomposan). Pemberian bahan organik tersebut diharapkan dapat meningkatkan kandungan hara N,P dan K.

Berdasarkan uraian di atas telah dilakukan penelitian dengan judul "Pengaruh Pemberian Beberapa Jenis Bahan Organik Terhadap Peningkatan Kandungan $\mathrm{H}$ ara N, P, K U Itisol".

\section{METODE PENELITIAN}

Penelitian berbentuk percobaan lapangan dilaksanakan di Kebun Percobaan Fakultas Pertanian Universitas Andalas Padang. Analisis tanah di Laboratorium Jurusan Tanah Fakultas Pertanian Universitas Andalas Padang. Penelitian dilaksanakan pada bulan Agustus - Oktober 2006. Bahan organik yang digunakan terdiri dari; Tithonia (Tithonia diversifolia), jerami padi, alang-alang (Imperata cylindrica), dan petai cina (Laucena glauca sp).

\section{Rancangan percobaan}

Rancangan percobaan digunakan yaitu Rancangan Acak Kelompok (RAK), dengan 5 perlakuan dan 3 (Kelompok). Data dianalisis dengan analisis sidik ragam dan uji lanjut Duncan's New Multiple Range Test (DNMRT) pada taraf nyata 5\%. Perlakuan terdiri dari :

$$
\begin{aligned}
& \text { A }=\text { Tanpa bahan organik }(\text { control }) \\
& B=\text { Tithonia } 20 \text { ton } / \mathrm{Ha} \\
& \text { C = Jerami padi } 20 \text { ton } / \mathrm{ha} \\
& \mathrm{D}=\text { Alang-alang } 20 \mathrm{ton} / \mathrm{ha} \\
& \mathrm{E}=\text { Petai cina } 20 \mathrm{ton} / \mathrm{ha}
\end{aligned}
$$

\section{Pelaksanaan Penelitian}

Pada tahap persiapan dilakukan berupa: (1) pengumpulan bahan tanaman yang akan dijadikan bahan organik, (2) Pembuatan plot-plot percobaan lahan berukuran $1 \mathrm{~m} \quad \mathrm{x} 1 \mathrm{~m}$ dengan cara mencangkul tanah sampai kedalaman sekitar $20 \mathrm{~cm}$, pengolahan ini dilakukan dengan cara mencangkul sebanyak 2 kali kemudian tanah diratakan.

Bahan organik yang digunakan terlebih dahulu dianalisis kadar $\mathrm{N}, \mathrm{P}$, dan $\mathrm{K}$ 
nya. Bahan organik yang sudah dipersiapkan (dipotong-potong/dicincang halus) dengan ukuran sekitar $3 \mathrm{~cm}$ yang terdiri dari tithonia, jerami padi, alang-alang dan petai cina kemudian diletakkan pada permukaan tanah untuk tiap petakan sesuai label yang telah ditentukan untuk masingmasing jenis bahan organik. Setelah itu bahan organik tersebut diaduk dengan tanah sampai bercampur secara keseluruhan, setelah itu disiram sampai pada keadaan kapasitas lapang, kemudian diinkubasi selama tiga bulan. Analisis kadar hara $(\mathrm{C}, \mathrm{N}$, $\mathrm{P}$, dan $\mathrm{K}$ ) tanah dilakukan diawal sebelum diberi bahan organik dan setelah diinkubasi 3 bulan.

\section{HASIL DAN PEMBAHASAN}

1. Kandungan Hara N,P,K Tanah Sebelum Perlakuan (Sebelum dan Sesudah Diolah)

Beberapa sifat kimia tanah yang dianalisis sebelum perlakuan adalah kandungan bahan organik, dan N,P, K tanah. Hasil analisis kandungan N,P,K tanah sebelum perlakuan dapat dilihat pada Tabel 1.

Berdasarkan hasil analisis tanah awal pada Tabel 1. terlihat bahwa sebelum diolah Ultisol memiliki sifat kimia tanah awalnya adalah kandungan hara $\mathrm{N}(0,37 \%)$ tergolong sedang, $\mathrm{P}(15,40 \mathrm{ppm})$ tergolong tinggi dan $\mathrm{K}\left(0,51 \mathrm{cmol} . \mathrm{kg}^{-1}\right)$ tergolong sedang.
Pada Tabel 1. juga terlihat bahwa tidak terjadi perbedaan perubahan beberapa sifat fisika dan kimia tanah akibat pengolahan tanah, meskipun ada penurunan dan peningkatan dari nilai yang diperoleh tapi masih pada kriteria yang sama sehingga pengaruhnya tidak begitu besar, untuk nilai BV tanah tidak mengalami perubahan, berarti struktur tanah yang awal tidak berubah meskipun telah dilakukan pengolahan.

Kandungan bahan organik tanah awal mengalami peningkatan dari kondisi tanah sebelum dan sesudah diolah yakni dari $2,9 \%$ menjadi $3,2 \%$ sebesar $1,1 \%$ meskipun masih pada kriteria yang saman. Hal ini terjadi akibat adanya sisa tanaman atau vegetasi yang ada di permukaan tanah mengalami dekomposisi, sehingga bahan organik meningkat. Adanya pengaruh pengolahan tanah mempengaruhi proses dekomposisi dalam tanah, sehingga bahan organik yang ada didalam tanah bertambah, seperti yang ditegaskan Syarief (1987), bahwa kondisi fisika tanah yang berubah akibat pengolahan menyebabkan kandungan bahan organik tersebut akan berubah juga.

$$
\text { Terjadinya }
$$

peningkatan permeabilitas pada tanah awal dari 4,3 $\mathrm{cm} /$ jam menjadi $7,3 \mathrm{~cm} /$ jam akibat dari pengolahan tanah dari criteria sedang menjadi agak cepat, karena jumlah sebaran pori didominasi oleh pori mikro yang dapat menghambat gerakan udara dan air sedangkan setelah tanah diolah sebaran pori pada tanah tersebut didominasi oleh pori mikro yang dapat memperlancar gerakan air

Tabel 1. Hasil analisis sifat fisika dan Kandungan N,P,K tanah sebelum perlakuan (sebelum dan sesudah diolah)

\begin{tabular}{lcccc}
\hline Parameter & $\begin{array}{l}\text { Sebelum } \\
\text { diolah }\end{array}$ & kriteria & $\begin{array}{l}\text { Sesudah } \\
\text { diolah }\end{array}$ & kriteria \\
\hline Bahan organik(\%) & 2,90 & rendah & 3,20 & Rendah \\
N-total (\%) & 0.37 & sedang & 0.45 & sedang \\
P-total (ppm) & 15.40 & Tinggi & 15,80 & Tinggi \\
K-total (cmol.kg & 0.51 & sedang & 0,55 & sedang \\
\hline
\end{tabular}


tanah, viskositas, bulk density tanah tersebut, sebaran pori dan beda potensial juga dapat menentukan nilai permeabilitas tanah (Luki,1999)

di dalam tanah. Permeabilitas merupakan pergerakan air dari media berpori dalam suasana jenuh. Banyaknya air yang dapat bergerak atau berpindah pada tanah ditentukan oleh sifat-sifat tanah itu sendiri. Kecepatan aliran pada media berpori sangat ditentukan oleh adanya kesinambungan antara tekanan, panjang dan penampang pori.

Jumlah total ruang pori (TRP) setelah tanah diolah secara angka mengalami sedikit peningkatan sebesar $0,9 \%$, meskipun masih pada criteria yang sama yakni criteria sedang. TRP merupakan jumlah pori makro dan pori mikro dalam tanah yang dapat mempengaruhi tingkat kepadatan suatu tanah. Adanya pengolahan tanah tidak berpengaruh secara nyata terhadap nilai TRP tanah setelah di olah, karena pengolahan tanah juga tidak mempengaruhi bobot isi dan struktur tanah.

Nilai PDC (pori drainase cepat) setelah diolah mengalami sedikit penurunan sebesar $0,75 \%$ volume, walaupun masih pada criteria yang sama yaitu kriteria sangat rendah, berarti pengolahan tanah memberikan pengaruh yang nyata terhadap nilai PDC tanah setelah diolah. Pori drainase cepat merupakan pori yang terisi udara pada waktu tanah dalam keadaan kapasitas lapang. Pori ini sangat mempengaruhi keberadaan oksigen di dalam tanah yang sangat diperlukan oleh mikroorganisme tanah dalam melakukan aktivitasnya, serta proses respirasi tanaman (Baver, 1978 cit soepardi 1989).

Seperti yang dijelaskan Syarief (1980), bahwa pori drainase cepat disebut juga sebagai pori aerase karena air yang berada dalam pori tanah bergerak cepat dan segera hilang yang selanjutnya pori tanah akan diisi oleh udara. Hal ini juga dipengaruhi oleh TRP dan kandungan bahan organic yang mengalami peningkatan.

Sementara nilai pori drainase lambat (PDL) mengalami peningkatan sebesar $1,89 \%$ volume juga pada criteria yang sama yakni sedang, peningkatan yang sedikit ini membuktikan bahwa pengolahan tanah mempengaruhi PDL setelah diolah. Pori drainase lambat merupakan pori yang berada antara kadar air kapasitas lapang dengan kadar air yang masih memungkinkan adanya pergerakan air ke bawah secara lambat karena pengaruh gaya gravitasi, dengan ukuran pori 8,7-29,7 mikron dan dinyatakan dengan persen volume.

Nilai PAT (pori air teredia) berada pada criteria tinggi, meskipun secara angka hanya sedikit mengalami peningkatan yakni sebesar $0,6 \%$ volume dari tanah sebelum diolah, ini terjadi akibat nilai PDC yang menurun dan PDL yang meningkat. Pori air tersedia (PAT) merupakan pori tanah dimana akar tanaman akan mampu menyerap air yang berada dalam pori-pori tanah.

Terjadinya penurunan pada persentase agregat setelah tanah diolah sebesar $0,7 \%$ meskipun pada kriteria yang sama, hal ini menunjukkan pengolahan tidak berpengaruh secara langsung terhadap proses agregasi yang terjadi dalam tanah meskipun tanah telah diolah, karena pengaruh aktivitas mikroorganisme di dalam tanah dapat menjadi faktor terjadinya pembentukan agregat tersebut.

Indeks kemantapan agregat Tropudults Limau Manis mengalami penurunan dari 214 menjadi 185 yakni sebesar 29 dari criteria sangat mantap sekali menjadi sangat mantap, berarti pengolahan tanah berpengaruh nyata terhadap nilai indeks kemantapan agregat, hal ini disebabkan kandungan bahan organic yang juga meningkat tingkat kegemburan tanah akibat pengolahan tanah tersebut.

\section{Sifat Kimia Tanah Setelah Perlakuan (Pemberian bahan organik).}

Beberapa sifat fisika dan kimia tanah yang dianalisis setelah pemberian bahan organik adalah: (1) kandungan bahan organik, (2) stabilitas agregat, dan (3) 
kandungan hara N, P, K. Hasil analisis ini di dapat dari hasil inkubasi bahan organik yang dicampur secara langsung kedalam tanah selama tiga bulan yakni hasil analisis dari tiap bulannya.

\section{Kandungan Karbon Organik}

Pengaruh pemberian beberapa jenis bahan organik terhadap kandungan bahan organik Tropudults Limau Manis dapat dilihat pada grafik 1 dibawah ini.

Berdasarkan grafik 1. menjelaskan bahwa, setelah pemberian pemberian perlakuan memberikan pengaruh yang nyata terhadap kandungan organik tanah, dibandingkan dengan kandungan bahan organik tanah tanpa perlakuan. Pada satu bulan setelah perlakuan, kandungan bahan organic titonia mengalami peningkatan tertinggi dibandingkan perlakuan lain yakni sebanyak $1,7 \%$ diikuti oleh perlakuan jerami padi dan perlakuan alang-alang yang hanya sedikit mengalami peningkatan kandungan bahan organic tanah antara lain sebesar $0,8 \%$ dan $0,3 \%$, sementara perlakuan petai cina mengalami peningkatan kandungan bahan organic yang agak besar sebesar 1,5\% bila dibandingkan dengan control.

Kondisi lain yang dapat mempengaruhi proses dekomposisi bahan organic seperti suhu dan temperature tanah, kandungan air, kedalaman tanah, dan vegetasi yang terdapat pada permukaan tanah tersebut. Seperti yang ditegaskan Hakim et al (1987), bahwa bila tanah cukup mengandung air dan udara, penguraian bahan organic berlangsung cepat. Akibatnya jumlah $\mathrm{CO} 2$ dalam tanah akan meningkat dan NO3 dalam tanah akan berkurang karena adanya pengikatan oleh jasad renik yang menguraikan bahan organic tersebut.

Menurut Purwowidodo (1983) untuk dapat terbentuknya bahan organik tanah memerlukan waktu tanam yang lama, sedangkan sample tanah yang diambil

Grafik .1. Pengaruh pemberian bahan organik terhadap kandungan bahan organik Tropudults Limau Manis

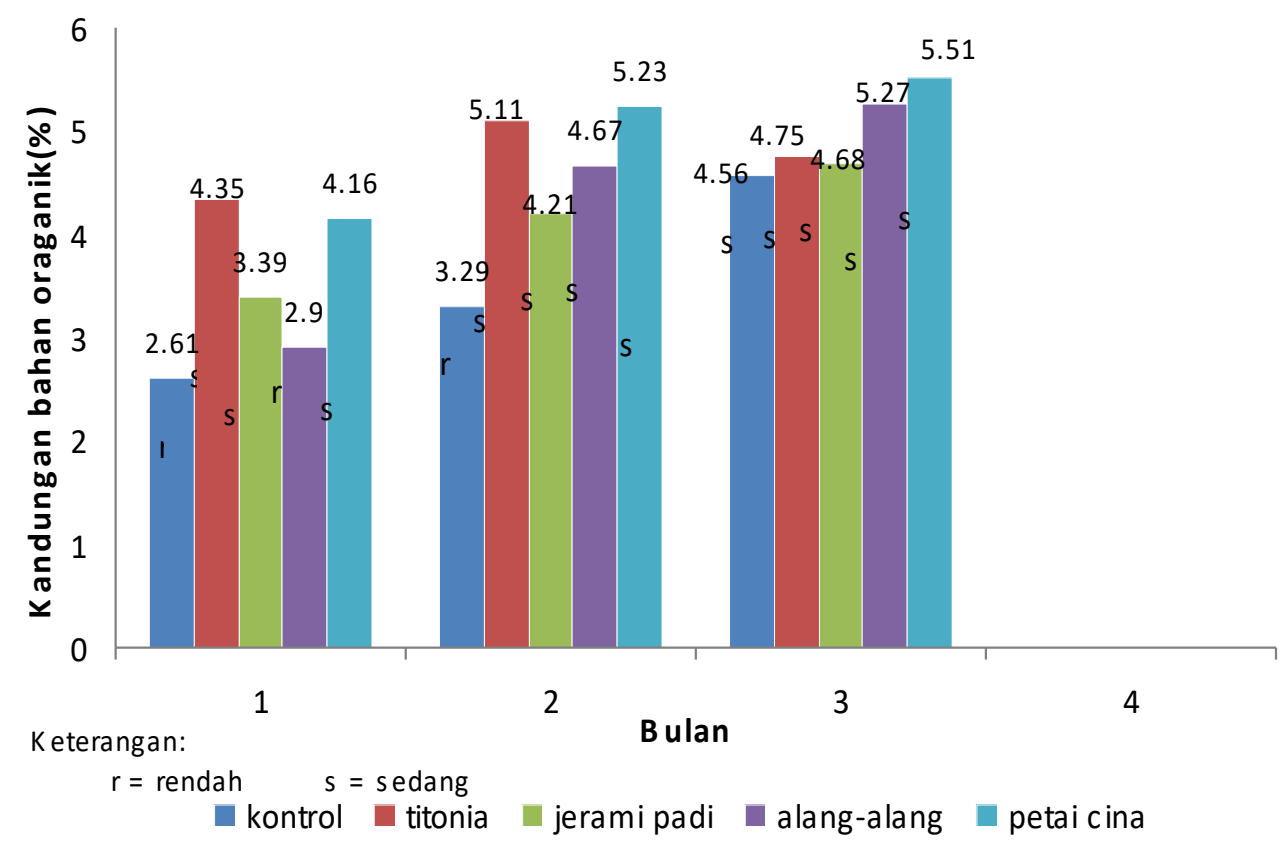


dalam penelitian ini hanya diambil 1 bulan sesudah inkubasi, disamping waktu, terbentuknya bahan organic dipengaruhi oleh beberapa faktor seperti jenis atau sumber bahan organik yang diberikan ke tanah serta suhu dan kelembaban tanah yang mempengaruhi proses pembentukan bahan organik tanah.

Dua bulan setelah pemberian bahan organik ke dalam tanah, masih memberikan pengaruh nyata terhadap kandungan bahan organik tanah, terlihat dari peningkatan kandungan bahan organic yang masih terjadi pada bulan ini dibandingkan bulan pertama. Perlakuan tithonia dan jerami padi memberikan pengaruh yang nyata terhadap kandungan bahan organic tanah tropudults Limau Manis, yakni dari peningkatan kandungan bahan organic perlakuan tithonia sebesar $1,82 \%$ dan perlakuan jerami padi sebesar $0,92 \%$, sedangkan alang-alang dan perlakuan petai cina memberikan pengaruh yang tidak nyata meskipun mengalami peningkatan kandungan bahan organic tanah sebesar $1,38 \%$ dan $1,94 \%$ dibandingkan dengan control.

Pada bulan ke tiga masing-masing pemberian bahan organic sudah tidak memberikan pengaruh yang nyata terhadap kandungan bahan organik meskipun secara angka mengalami peningkatan. Masingmasing perlakuan mengalami peningkatan kandungan bahan organic bila dibandingkan bulan kedua, ini terjadi karena bahan organic yang diberikan ke dalam tanah sudah mengalami dekomposisi secara keseluruhan atau sempurna. Seluruh perlakuan mengalami peningkatan kandungan bahan organic, perlakuan titonia meningkat sebesar $1,19 \%$, jerami padi sebesar $0,12 \%$, alang-alang $0,71 \%$ dan petai cina $0,95 \%$ dibandingkan dengan control, sedangkan bila dibandingkan dari bulan kedua, seluruh perlakuan mengalami peningkatan kandungan bahan organic, perlakuan titonia sebesar $0,6 \%$, perlakuan jerami padi sebesar $0,47 \%$, perlakuan alangalang $0,6 \%$ dan petai cina $0,28 \%$.

\section{Kandungan hara N, P dan $\mathrm{K}$ tanah}

Hasil analisis kandungan hara N,P dan $\mathrm{K}$ setelah pemberian beberapa macam bahan organik ditampilkan pada Tbael 2. Dari Tabel 2. terlihat bahwa pemberian hijauan bahan organik terjadi peningkatan kandungan hara $\mathrm{N}, \mathrm{P}$ dan $\mathrm{K}$ tanah. Tithonia meningkatkan $\mathrm{N}(0,1 \%), \mathrm{P}$ (8 ppm), K $(0,73 \mathrm{cmol} / \mathrm{kg})$, Jerami Padi meningkatkan $\mathrm{P}(2 \mathrm{ppm}), \mathrm{K}(0,16 \mathrm{cmol} / \mathrm{kg})$, alang-alang meningkatkan $\mathrm{P}(3 \mathrm{ppm}), \mathrm{K}$ $(1,15 \quad \mathrm{cmol} / \mathrm{kg})$, dan petai cina meningkatkan $\mathrm{P}(2 \mathrm{ppm}), \mathrm{K}(0,008 \mathrm{cmol} / \mathrm{kg})$.

Dari hasil analisis tersebut di atas terlihat bahwa tithonia merupakan bahan organik yang dapat memberikan peningkatan hara $\mathrm{N}, \mathrm{P}$,dan $\mathrm{K}$ yang tertinggi dibandingkan bahan organik lainnya (jerami padi, alang-alang dan petai cina), hal ini disebabkan karena hijauan tithonia selain dapat dijadikan sebagai sumber bahan

Tabel 2. Hasil analisis N-total, P-tersedia dan K-dd tanah setelah pemberian beberapa macam bahan organik

\begin{tabular}{|c|c|c|c|}
\hline Perlakuan & N-total (\%) & P-tersedia (ppm) & $\begin{array}{c}\text { K-dd } \\
\left(\mathrm{cmol}_{\mathrm{kg}}{ }^{-1}\right)\end{array}$ \\
\hline A & 0,3 & 15,9 & 0,54 \\
B & 0,5 & 16,6 & 1,28 \\
C & 0,4 & 16,0 & 0,91 \\
D & 0,3 & 16,1 & 1,7 \\
E & 0,4 & 16,0 & 0,63 \\
\hline
\end{tabular}


organik juga sekaligus dapat digunakan sebagai sumber hara terutama $\mathrm{N}, \mathrm{K}$ karena tithonia mengandung $\mathrm{N}$ dan $\mathrm{K}$ yang cukup tinggi yaitu sekitar $3,5 \% \mathrm{~N}, 0,37 \% \mathrm{P}$ dan 4,1\% K sehingga dapat menjadi sumber $\mathrm{N}$, P, dan K bagi tanaman (Jama, Palm, Buresh, Niang, Gachego, Nziguheba, and Amadado ,2000). Bahan organik tithonia juga dapat mensubstitusi pupuk buatan Urea, dan $\mathrm{KCl}$ sesuai yang dilaporkan oleh Gusmini et al (2003), bahwa Kombinasi 68 $\%$ NK dari tithonia dan $32 \%$ NK dari pupuk buatan adalah kombinasi yang terbaik dalam mensubsitusi pupuk buatan dengan hijauan tithonia untuk memperoleh pertumbuhan dan hasil rimpang jahe tertinggi pada Ultisol.

Peningkatan P-tersedia dapat juga disebabkan oleh aplikasi tithonia mampu menurunkan $\mathrm{P}$ yang teradsorpsi dalam tanah. Dari pelapukan tithonia akan dihasilkan asam-asam organik yang memegang peranan penting dalam pengikatan $\mathrm{Al}$ dan $\mathrm{Fe}$, sehingga $\mathrm{P}$ menjadi tersedia.

Peningkatan N-total tanah jelas dipengaruhi oleh pemberian hijauan tithonia ke tanah, karena kadar $\mathrm{N}$ tithonia yang cukup tinggi yaitu 2,8 \%. Pemberian tithonia berperan penting dalam meningkatkan N-total tanah seperti yang dilaporkan oleh Gachengo et al (1999), bahwa kadar $\mathrm{N}$ tithonia yang tinggi, dan cepat melapuk menjadikan tithonia sebagai sumber $\mathrm{N}$ yang efektif bagi tanaman. Peningkatan kadar N-total tanah dapat disebabkan oleh pelapukan bahan organik yang meningkatkan aktivitas mikroorganisme tanah.

\section{KESIMPULAN} disimpulkan bahwa:

Berdasarkan hasil penelitian dapat

1. Pemberian beberapa jenis BO dapat meningkatkan kandungan $\mathrm{BO}$ Ultisol Limau Manis. Tithonia meningkatkan kandungan BO sebesar $1,19 \%$, jerami padi $0,95 \%$, alang-alang $0,17 \%$ dan petai cina $0,12 \%$ setelah 3 bulan pemberian 20 ton $\mathrm{BO} / \mathrm{ha}$.
2. Pemberian BO meningkatkan kandungan hara $\mathrm{N}, \mathrm{P}$ dan $\mathrm{K}$ tanah. Tithonia meningkatkan $\mathrm{N}(0,1 \%), \mathrm{P}$ (8 ppm), K (0,73 cmol/kg), Jerami Padi meningkatkan $\mathrm{P}$ (2 ppm), K $(0,16 \quad \mathrm{cmol} / \mathrm{kg}), \quad$ alang-alang meningkatkan $\mathrm{P}$ (3 ppm), K (1,15 $\mathrm{cmol} / \mathrm{kg})$, dan petai cina meningkatkan P (2 ppm), K (0,008 $\mathrm{cmol} / \mathrm{kg}$ ). Tithonia memberikan peningkatan hara $\mathrm{N}$, $\mathrm{P}$, dan $\mathrm{K}$ yang tertinggi dibandingkan jerami padi, alang-alang dan petai cina.

\section{UCAPAN TERIMA KASIH}

Penulis mengucapkan terima kasih kepada proyek SP 4 Universitas Andalas atas bantuan finansialnya sehingga penelitian dan penulisan ini dapat terlaksana.

Daftar Pustaka

Andriyadi. 2002. Peranan rawmix dan limbah cair Kelapa Sawit terhadap beberapa sifat fisika Ultisol serta hasil Kedelai. Skripsi. Fakultas Pertanian. Universitas Andalas. Padang. 85 hal.

Amir, J. 1987. Erosi dan masalahnya pada tanah Podzolik. Laporan penelitian Fakultas Pertanian. Padang. 85 hal

Deswita, V. 2005. Pengaruh jarak tanam dan input pupuk terhadap hasil biomassa dan kandungan unsur hara Titonia (tithonia diversifolia). Skripsi. Fakultas Pertanian. Universitas Andalas. Padang. 60 hal.

Donahue, L. R. 1977. Soil introduction to Soil and plant growth. Fourth Edition Prentice Hall, Inc. Englewood. Cliffs. 626 pp.

Fiantis, D. 2004. Morfologi dan klassifikasi tanah. Jurusan Tanah. Fakultas Pertanian Universitas Andalas. Padang. 156 hal. 
Gachengo, C.N., C.A. Palm., B.A. Jama and C.Othieno. 1999. Tithonia and sauna green manures and inorganic fertilization as phosphorus sources for maize in western. Kenya. Agroforestry system. 44 : 21-36

Gusmini, Nurhayati Hakim, dan Eti Farda Husin. 2003. Substitusi NK pupuk buatan dengan NK tithonia (Tithonia diversifolia) untuk tanaman jahe pada Ultisol. Prosiding Kongres Nasional VIII HITI 21-24 Juli 2003 di Padang.

Hakim. N, Lubis,A.M, Pulung, M.A, Nyakpa,M.Y, Amrah, Hong,G.B 1987. Pupuk dan pemupukan. BKS-PTN-Barat/ WUAE Project. Palembang. 286 hal.

Hakim, N . 2003. Penuntun praktikum dasar-dasar Ilmu Tanah. Fakultas Pertanian. Universitas Andalas. Padang. 20 hal.

Hardjowigeno, S. 1987. Ilmu tanah. Akademika Pressindo. Jakarta . 286 hal

Imbang, I. N Datuk Rajo., A, Rasyidin, Adrinal. L. Maira, dan Hermansah, 1994. Klasifikasi tanah kebun percobaaan fakultas pertanian universitas andalas di limau manis kotamadia padang. Laporan Pernelitian OPF. Lembaga Penelitian Universita Andalas. 50 hal.

Jama.B.A., C.A. Palm., R.J.Buresh., A. I. Niang., C. Gachego., G. Nziquheba and B.Amadado. 2000. Tithonia Diversifolia as a green manure for improvement of soil fertility in western Kenya. A Review.Agroforestry Systems.

Kertasapoetra, G. 1989. Kerusakan tanah pertanian dan usaha untuk rehabilitasinya. Bina Aksara. 237 hal.

Lestari, R. 2005. Kajian perubahan sifat fisika dan bahan organik tanah setelah 8 tahun pada lahan kritis Singkarak studi kasus Nagari Paninggahan. Skripsi Fakultas Pertanian. Universitas Andalas. Padang. 43 hal.

Luki, U. 1999. Fisika tanah terapan I (Matrik tanah). Jurusan Tanah. Fakultas Pertanian. Padang. 123 hal

Munir, M. 1995. Tanah-tanah utama Indonesia (Karakteristik, klassifikasi dan pemanfaatannya). Pustaka Jaya. 344 hal.

Nedrawati. 2006. Pengaruh pemberian bokasi tithonia diversifolia terhadap perubahan beberapa sifat fisika Ultisol Limau Manis. Skripsi Fakultas Pertanian. Universitas Andalas. Padang. 59 hal.

Purwowidodo. 1983. Telaah kesuburan tanah. Penerbit angkasa. Bandung. 275 hal

Ridwan, M. 1985. Peranan mulsa terhadap konservasi tanah dan air. Fakultas Pertanian Pasca Sarjana. IPB. Bogor. 30 hal.

Rinsema, W. J. 2983. Pupuk dan cara pemupukan. Bhatara Karya Aksara. Jakarta. 234 hal

Saidi, A. 2006. Fisika tanah dan lingkungan. Andalas University press. Padang. 367 hal

Sanchez, P. A. and B. A. Jama. 2000. Soil fertility replenishment takes off in East sand Southern Africa. International Symposium on Balanched Nutrient Management System for The Moist Savanna and Forest Zones of Africa. Held on 9 October 2000 in Benin. Africa. 
Sarief, S. 1980. Fisika tanah dasar. Serial Publikasi Ilmu Tanah. Fakultas Pertanian. Universitas Padjadjaran. Bandung. 145 hal 1985. Konservasi tanah dan air. Serial Publikasi Ilmu Tanah. Fakultas Pertanian. Universitas Padjadjaran. Bandung. 145 hal.

Siregar, H. 1981. Budidaya tanaman Padi di Indonesia. Sastra Hudaya. Jakarta. 200 hal.

Soegiman. 1982. Ilmu tanah. Terjemahan dari the nature and properties of soil. by H.O. Buckman dan N. C. Brady. Bharata Karya Bogor. Bharata Karya Aksara. Jakarta. 788 hal.

Soepardi, G. 1983. Sifat dan ciri tanah. Institut pertanian Bogor. Bogor. 591 hal.
Soewardjo dan Sinukaban, N. 1986. Masalah erosi dan kesuburan tanah di lahan Podsolik Merah Kuning di Indonesia. Lokakarya usaha tani konservasi lahan Alang-alang Podsolik Merah Kuning. Badan Litbangtan. DirjenTanaman pangan. Palembang.

Yulnafatmawita. 2004. Penuntun praktikum fisika tanah. Fakultas Pertanian Universitas Andalas. Padang. 63 hal.

Zulhadi. 2006. Pengaruh pemberian pupuk hijau dan bokasi tithonia diversifolia terhadap perubahan beberapa sifat fisika Ultisol Limau Manis. Skripsi . Fakultas Pertanian. Universitas Andalas. Padang. 55 hal. 